\title{
ЕПІДЕМІОЛОГІЧНІ ОСОБЛИВОСТІ ПОШИРЕННЯ ГАСТРОЕЗОФАГЕАЛЬНОЇ РЕФЛЮКСНОЇ ХВОРОБИ СЕРЕД ДІТЕЙ ЛЬВІВСЬКОЇ ОБЛАСТІ
}

\author{
М.І. Дац-Опока, Н.С. Косминіна, Л.Ф. Бура-Ярошевич, О.Р. Трутяк
}

Львівський нащіональний медичний університет імені Данила Галицького, кафедра пропедевтики педіатрії та медичної генетики, м. Львів, Україна,

ORCID ID: 0000-0002-2797-2462, ORCID ID: 0000-0003-0422-7002,

ORCID ID: 0000-0002-3244-2191, ORCID ID: 0000-0002-7777-9927,

e-mail:martadats@gmail.com

Резюме. Метою дослідження було проаналізувати рівень захворюваності на гастроезофагеальну рефлюксну хворобу (ГЕРХ) серед дітей до 14 років у Львівській області.

Проведено ретроспективний аналіз епідеміології ГЕРХ серед дітей Львівської області у 2013-2016 роках.

Відповідно до результатів, спостерігається тенденція до зростання поширеності ГЕРХ серед дітей Львівської області - із 0,66 вип./1 тис.дит.нас. у 2013 році до 1,15 вип./1 тис.дит.нас. у 2016 році (темп приросту $\mathrm{T}_{\text {пр }}=+66,67 \%$ ). Найвищий рівень загальної захворюваності як у Львівській області, так і у містах регіону спостерігався у 2015 році, а у сільській місцевості - у 2014 році.

Оцінюючи рівень поширеності ГЕРХ у розрізі районів Львівщини, встановлено, що найвищий рівень поширеності ГЕРХ серед всіх районів зареєстровано у Старосамбірському районі - 7,40 вип./1тис.дит.нас. (2014 р.), а серед міст - у м. Червоноград - 5,15 вип./1тис.дит.нас. (2016 р.). Найвищий рівень поширеності ГЕРХ як в цілому у Львівській області, так і у міських поселеннях регіону спостерігався у 2015 році - 1,19 вип./1тис.дит.нас. (480 випадків) та 1,25 вип./1тис.дит.нас. (196 випадків) відповідно. У сільській місцевості найвищий рівень поширеності ГЕРХ був у 2014 році - 1,20 вип./1тис.дит.нас. (292 випадки).

Захворюваність на ГЕРХ є вищою у дівчаток, ніж у хлопчиків протягом всіх років спостереження. У групі дітей 0-6 років захворюваність на ГЕРХ знижується, а у групі дітей 7-14 років - зростає.

Підсумовуючи, поширеність ГЕРХ серед дітей Львівської області зростає, що є більш вираженим у міських поселеннях. За останній аналізований рік найвищі рівні поширеності ГЕРХ реєструються на півночі та півдні області, найнижчі або відсутні - в центральних, західних та східних районах Львівщини.

«Територіями ризику», за показником поширення ГЕРХ, можна вважати: Старосамбірський, Сколівський, Сокальський, Буський райони Львівської області та м. Червоноград і м. Моршин. Рівень первинної захворюваності та поширеності ГЕРХ є вищим у дівчаток, ніж у хлопчиків. На всіх територіях Львівщини за усі роки спостереження вища захворюваність була у школярів порівняно $з$ дошкільнятами.

Ключові слова: гастроезофагеальна рефлюксна хвороба, діти, Львівська область, епідемілогія

Вступ. Поширеність гастроезофагеальної рефлюксної хвороби (ГЕРХ) у загальній популяції знаходиться в межах 20-40 \% у США та Європі і $12 \%$ у Бразилії [1, 2, 3, 4], а у дітей коливається, за даними різних авторів, від 2-4 \% до 8,7-49\%, і показник щороку зростає [5]. Широка розповсюдженість ГЕРХ обумовлює значні фінансові витрати на діагностику та лікування цього захворювання. Наприклад, щорічно в США пацієнти, що страждають на печію, споживають різноманітних антацидних засобів на 900 млн. доларів [6].

Діагностика ГЕРХ у дітей ускладнюється наявністю ендоскопічно-негативної форми, яка часто розглядається як попередник ендоскопічно- позитивної ГЕРХ, відсутністю виражених клінічних симптомів у дитячому віці та наявністю екстраезофагеальних симптомів, які можуть маскувати перебіг ГЕРХ, що утруднює своєчасне встановлення діагнозу та призводить до гіпердіагностики деяких захворювань [7]

Обгрунтування дослідження. У сучасній науковій літературі інформації про захворюваність на
ГЕРХ серед дітей є обмаль. Зокрема, бракує даних про епідеміологію та структуру захворюваності на ГЕРХ серед дітей $[5,8]$

Мета дослідження. Визначити i проаналізувати епідеміологію захворюваності на ГЕРХ серед дітей (0-14 p) Львівської області у розрізі районів.

Матеріали і методи. Проведено ретроспективний аналіз показників поширення та первинної захворюваності на ГЕРХ серед дітей Львівської області у 2013-2016 роках, за даними узагальненого звіту ф. № 12 «Звіт про захворювання, зареєстровані у хворих, які проживають у районі обслуговування лікувально-профілактичного закладу, за рік». Критерії включення: 1) діти віком 0-14 років, що проживали на момент виконання дослідження у м. Львів та Львівській області та мали діагностовану ГЕРХ, 2) добровільна інформована згода на участь у дослідженні. Критерії виключення: 1) діти, старші 14 років, 2) діти з інших областей України, 3) відмова від участі у дослідженні на будь-якому етапі. Усі діти 
були поділені за статтю, віком та місцем проживання, а також за різними роками спостереження.

Результати дослідження та обговорення. При статистичному аналізі захворюваності на ГЕРХ протягом 2013-2016 років прослідковується стійке зростання поширеності та первинної захворюваності на ГЕРХ серед дітей Львівської області - із 0,66 вип./1тис.дит.нас. у 2013 році до 1,15 вип./1тис.дит.нас. у 2016 році (темп приросту $\mathrm{T}_{\text {пр }}=+66,67 \%$ ) (табл. 1 , рис. 1 ).
Найбільше поширеність на ГЕРХ спостерігалася у 2015 році - 1,19 вип./1тис.дит.нас. (480 випадків) та 1,25 вип./1тис.дит.нас. (196 випадків) відповідно. Найбільше зростання даного показника

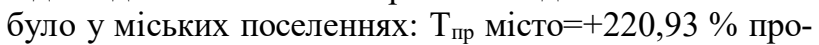
ти $\mathrm{T}_{\text {пр }}$ село $=+26,25 \%$ відповідно. Серед хворих, які проживають у сільській місцевості, найвищий рівень поширеності ГЕРХ був у 2014 році - 1,20 вип./1тис.дит.нас. (292 випадки).

Таблиця 1.

Показники поширення та первинної захворюваності на ГЕРХ у дітей Львівської області за 2013-2016 роки

\begin{tabular}{|c|c|c|c|c|c|c|c|c|c|}
\hline \multirow[b]{2}{*}{ Території } & \multirow{2}{*}{$\begin{array}{c}\text { Показник } \\
\text { и }\end{array}$} & \multicolumn{2}{|c|}{2013} & \multicolumn{2}{|c|}{2014} & \multicolumn{2}{|c|}{2015} & \multicolumn{2}{|c|}{2016} \\
\hline & & $\begin{array}{l}\text { абс. } \\
\text { дані }\end{array}$ & $\begin{array}{c}\text { на 1тис. } \\
\text { дит. } \\
\text { нас. }\end{array}$ & $\begin{array}{l}\text { абс. } \\
\text { дані }\end{array}$ & $\begin{array}{c}\text { на 1тис. } \\
\text { дит. } \\
\text { нас. }\end{array}$ & $\begin{array}{l}\text { абс. } \\
\text { дані }\end{array}$ & $\begin{array}{c}\text { на 1тис. } \\
\text { дит. } \\
\text { нас. }\end{array}$ & $\begin{array}{l}\text { абс. } \\
\text { дані }\end{array}$ & $\begin{array}{c}\text { на 1тис. } \\
\text { дит. } \\
\text { нас. }\end{array}$ \\
\hline \multirow{2}{*}{$\begin{array}{l}\text { Сільська } \\
\text { місцевість }\end{array}$} & Пошир. & 195 & 0,80 & 292 & 1,20 & 284 & 1,15 & 251 & 1,01 \\
\hline & Захвор. & 159 & 0,65 & 196 & 0,80 & 121 & 0,49 & 98 & 0,39 \\
\hline \multirow{2}{*}{$\begin{array}{l}\text { Міські } \\
\text { поселення }\end{array}$} & Пошир. & 65 & 0,43 & 171 & 1,11 & 196 & 1,25 & 219 & 1,38 \\
\hline & Захвор. & 25 & 0,16 & 82 & 0,53 & 74 & 0,47 & 51 & 0,32 \\
\hline \multirow{2}{*}{$\begin{array}{l}\text { Львівська } \\
\text { область }\end{array}$} & Пошир. & 260 & 0,66 & 463 & 1,16 & 480 & 1,19 & 470 & 1,15 \\
\hline & Захвор. & 184 & 0,46 & 278 & 0,70 & 195 & 0,48 & 149 & 0,36 \\
\hline
\end{tabular}

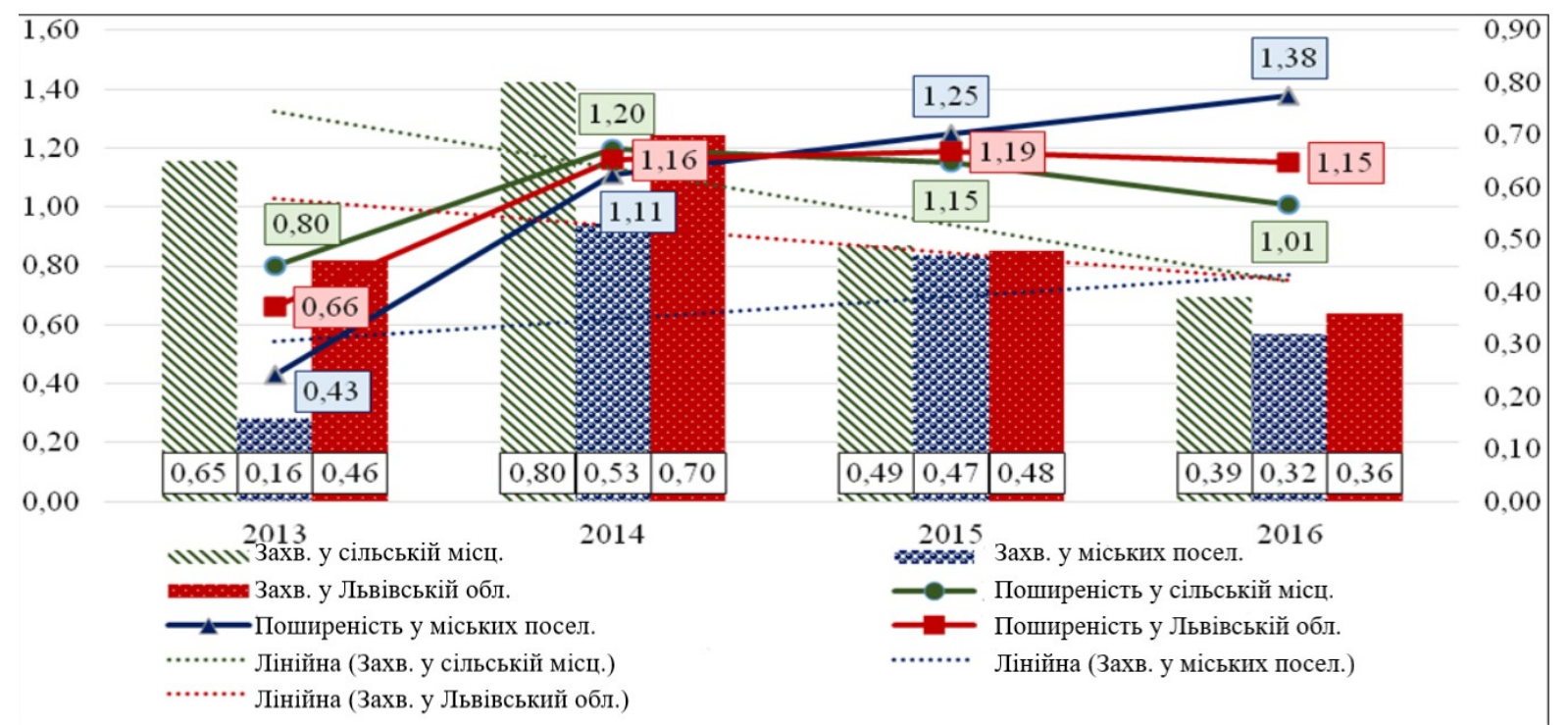

Рис. 1. Рівні поширення та первинної захворюваності ГЕРХ у дітей Львівської області протягом 20132016 років (на 1 тис. дит. нас.)

Найвищий рівень первинної захворюваності в усій області спостерігався у 2014 році. Порівнюючи показники захворюваності на міських та сільських територіях було встановлено, що первинна захворюваність на ГЕРХ протягом аналізованого періоду була вищою у сільській місцевості, тоді як поширеність ГЕРХ у 2015 і 2016 роках була вищою у міських поселеннях - 1,25 вип./1тис.дит.нас. та 1,38 вип./1тис.дит.нас., відповідно. За рівнем первинної захворюваності на ГЕРХ 32015 року наявний поступовий спад захворюваності як в цілому по області, так і в сільській місцевості: $\mathrm{T}_{\text {пр обл. }=-21,74}$ $\%$ та $\mathrm{T}_{\text {пр }}$ село $=-40,00 \%$. Тоді як у міських поселеннях наявна тенденція до зростання вперше зареєстрованих випадків ГЕРХ за 4 роки

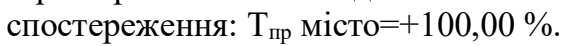

Оцінюючи структурний рівень поширеності ГЕРХ районів Львівщини (табл.2), встановлено, що найвищий показник зареєстровано у Старосамбірському районі - 7,40 вип./1тис.дит.нас. (2014р.), серед міст - у м.Червоноград $-5,15$ вип./1тис.дит.нас. (2016 р.). Слід зауважити, що дані території мали високі показники кожного року протягом періоду спостереження. Високі показники (вище середньообласних показників - 1,15-1,19 вип./1тис.дит.нас.) поширеності протягом кількох років ще були у Бусь- 
кому (2,04-2,34 вип./1тис.дит.нас.), Жовківському (1,69-2,06 вип./1тис.дит.нас.) та Сокальському (1,842,60 вип./1тис.дит.нас.) районах і м. Львів (1,17-1,28 вип./1тис.дит.нас.) та м. Моршин $(1,40-2,84$ вип./1тис.дит.нас.). Аналізуючи окремо кожний рік спостереження, можна виділити такі території із найвищими показниками поширеності ГЕРХ: у 2013 році - Старосамбірський, Сколівський, Самбірський, Буський та Сокальський райони, м. Червоноград та м. Моршин; у 2014 році - Старосамбірський, Сколівський, Жидачівський, Жовківський, Буський та Сокальський райони, м. Червоноград та м. Моршин; у 2015 році - Старосамбірський, Сколівський, Буський, Сокальський, Бродівський та Жовківський райони, м. Червоноград та м. Моршин; у 2016 році - Сколівський, Кам'янко-Бузький, Сокальський, Буський, Жовківський райони, м. Червоноград, м. Моршин та м. Львів. Враховуючи загальну тенденцію до зростання та високі показники поширеності ГЕРХ, можна виділити так звані «території ризику», за показником поширення ГЕРХ: Старосамбірський, Сколівський, Сокальський, Буський райони та м.Червоноград і м. Моршин.

Найнижчі показники поширеності ГЕРХ серед дітей відмічались у Городоцькому, Миколаївському, Перемишлянському та Стрийському районах. У Мостиському районі та м. Трускавець і м. Стрий не було зареєстровано жодного випадку ГЕРХ впродовж 4-х років спостереження.

За даними картодіаграми (рис. 2), найвищі рівні поширеності ГЕРХ за 2016 рік реєструються на півночі та півдні області, найнижчі або відсутні взагалі - в центральних, західних та східних регіонах Львівської області.

Таблиця 2.

Рівні поширення ГЕРХ серед дітей у розрізі районів Львівської області впродовж 2013-2016 років

\begin{tabular}{|c|c|c|c|c|c|c|c|c|}
\hline \multirow[t]{2}{*}{ Території } & \multicolumn{4}{|c|}{ Абсолютні дані } & \multicolumn{4}{|c|}{$\begin{array}{c}\text { Випадків на } \\
1 \text { тис. дит. нас. }\end{array}$} \\
\hline & 2013 & 2014 & 2015 & 2016 & 2013 & 2014 & 2015 & 2016 \\
\hline \multicolumn{9}{|c|}{ Райони } \\
\hline Бродівський & 6 & 2 & 21 & 6 & 0,59 & 0,20 & 2,07 & 0,59 \\
\hline Буський & 9 & 16 & 20 & 19 & 1,15 & 2,04 & 2,50 & 2,34 \\
\hline Городоцький & 2 & 2 & 0 & 0 & 0,18 & 0,18 & 0 & 0 \\
\hline Дрогобицький & 1 & 4 & 5 & 6 & 0,08 & 0,32 & 0,40 & 0,47 \\
\hline Жидачівський & 1 & 27 & 1 & 5 & 0,10 & 2,59 & 0,10 & 0,48 \\
\hline Жовківський & 14 & 40 & 34 & 34 & 0,73 & 2,06 & 1,71 & 1,69 \\
\hline Золочівський & 3 & 3 & 4 & 6 & 0,27 & 0,27 & 0,36 & 0,54 \\
\hline Кам.-Бузький & 1 & 7 & 5 & 28 & 0,10 & 0,72 & 0,51 & 2,80 \\
\hline Миколаївський & 0 & 1 & 3 & 3 & 0 & 0,09 & 0,28 & 0,27 \\
\hline Перемишлянський & 1 & 1 & 1 & 0 & 0,16 & 0,16 & 0,16 & 0 \\
\hline Пустомитівський & 18 & 23 & 16 & 18 & 0,98 & 1,22 & 0,83 & 0,91 \\
\hline Радехівський & 0 & 4 & 4 & 7 & 0 & 0,49 & 0,49 & 0,85 \\
\hline Самбірський & 21 & 7 & 8 & 11 & 1,22 & 0,41 & 0,46 & 0,63 \\
\hline Сколівський & 32 & 32 & 28 & 28 & 3,48 & 3,45 & 2,97 & 2,97 \\
\hline Сокальський & 17 & 28 & 31 & 40 & 1,11 & 1,84 & 2,02 & 2,60 \\
\hline Ст. Самбірський & 69 & 91 & 81 & 12 & 5,62 & 7,40 & 6,53 & 0,97 \\
\hline Стрийський & 0 & 1 & 2 & 5 & 0 & 0,10 & 0,20 & 0,48 \\
\hline Турківський & 0 & 0 & 4 & 4 & 0 & 0 & 0,38 & 0,39 \\
\hline Яворівський & 0 & 3 & 16 & 19 & 0 & 0,13 & 0,67 & 0,79 \\
\hline Разом райони & 195 & 292 & 284 & 251 & 0,80 & 1,20 & 1,15 & 1,01 \\
\hline \multicolumn{9}{|c|}{ Міста } \\
\hline Львів & 38 & 124 & 122 & 141 & 0,36 & 1,17 & 1,12 & 1,28 \\
\hline Борислав & 0 & 3 & 2 & 2 & 0 & 0,49 & 0,33 & 0,33 \\
\hline Дрогобич & 0 & 1 & 5 & 5 & 0 & 0,08 & 0,37 & 0,37 \\
\hline Моршин & 1 & 2 & 2 & 2 & 1,40 & 2,84 & 2,79 & 2,84 \\
\hline Новий Розділ & 1 & 0 & 2 & 5 & 0,22 & 0 & 0,46 & 1,16 \\
\hline Червоноград & 25 & 41 & 63 & 64 & 2,08 & 3,38 & 5,11 & 5,15 \\
\hline Разом міста & 65 & 171 & 196 & 219 & 0,43 & 1,11 & 1,25 & 1,38 \\
\hline $\begin{array}{l}\text { Разом } \\
\text { Львівська обл. }\end{array}$ & 260 & 463 & 480 & 470 & 0,66 & 1,16 & 1,19 & 1,15 \\
\hline
\end{tabular}




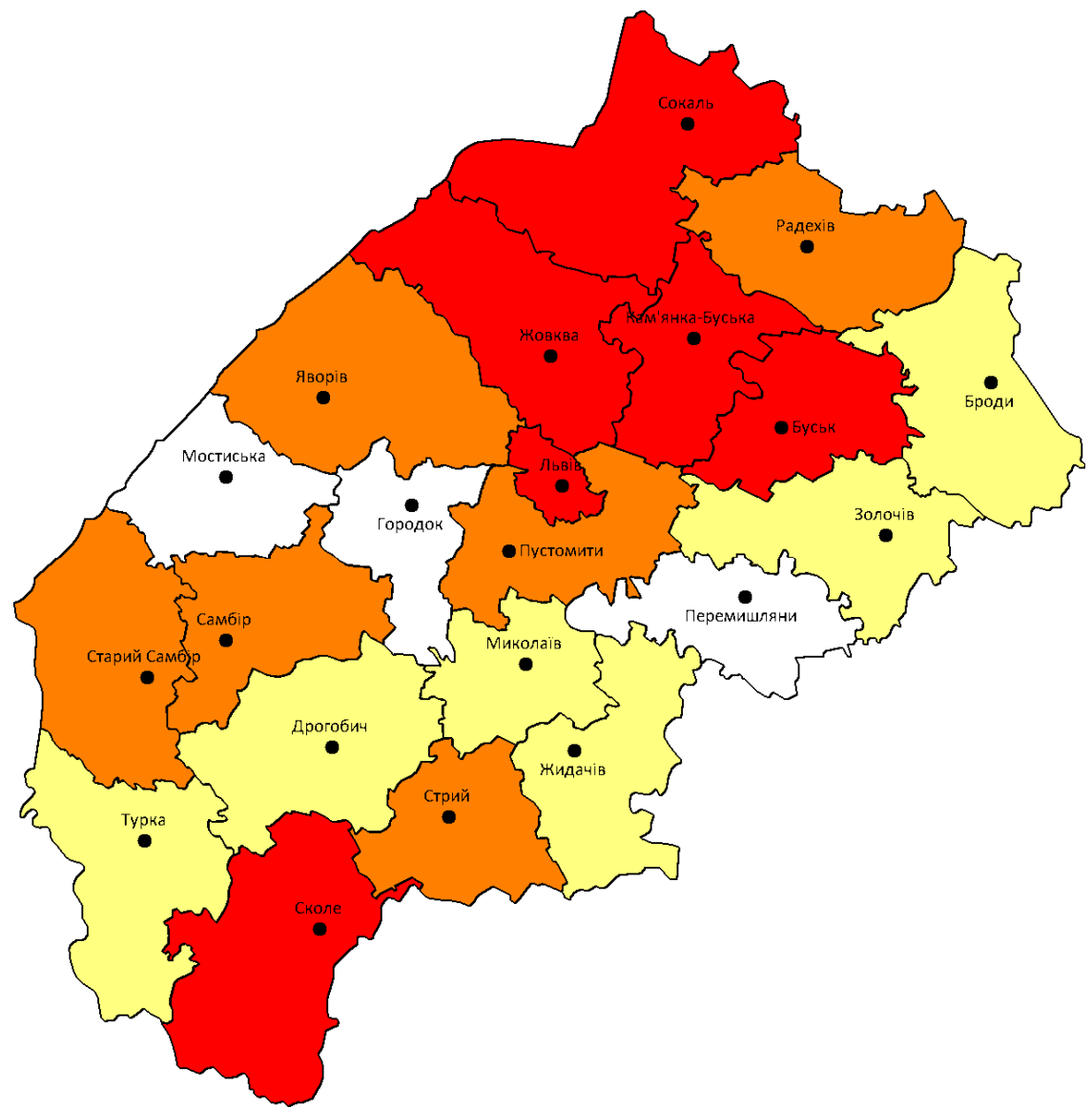

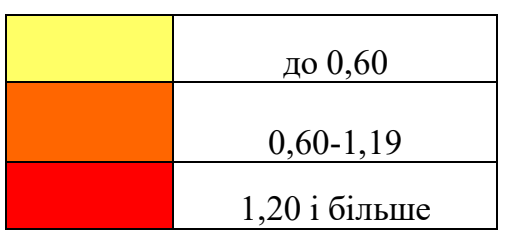

Рис. 2. Картодіаграма розподілу показників поширеності ГЕРХ серед дітей у розрізі районів Львівської області у 2016 році (випадків на 1 тис. дит. нас.)
Високі рівні первинної захворюваності на ГЕРХ у дітей протягом кількох років реєструвались у Старосамбірському $(5,62-7,40$ вип./1тис.дит.нас.), Сколівському (2,01-2,48 вип./1тис.дит.нас.), Пустомитівському (0,60-0,96 вип./1тис.дит.нас.), Жовківському (0,63-0,88 вип./1тис.дит.нас.) районах та м. Червоноград (1,05-1,87 вип./1тис.дит.нас.) (табл. 3).

Майже у всіх районах області спостерігається тенденція до зниження реєстрації випадків первинного ГЕРХ, окрім Кам'янка-Бузького ( $\left.\mathrm{T}_{\text {пр }}=+1000 \%\right)$, Стрийського ( $\left.\mathrm{T}_{\text {пр }}=+190 \%\right)$, Турківського $\left(\mathrm{T}_{\text {пр }}=+105,26 \%\right)$ районів та м. Новий Розділ $\left(\mathrm{T}_{\text {пр }}=+213,64 \%\right)$, в яких $є$ тенденція до зростання.

У 2013 році територіями, де зареєстровано перевищення середньообласного показника ГЕРХ, були Старосамбірський, Сколівський, Пустомитівський та Самбірський райони і м. Моршин та м. Червоноград; у 2014 році - Старосамбірський, Сколівський, Буський, Пустомитівський та Жовківський райони i м. Червоноград та м. Моршин; у 2015 році - Старосамбірський, Сколівський, Бродівський та Буський райони і м. Червоноград; у 2016 році - Сколівський, Кам'янка-Бузький, Сокальський, Пустомитівський та Старосамбірський райони і м. Червоноград та м. Новий Розділ. Враховуючи високі показники первинної захворюваності впродовж кількох років та тенденції до їх зростання, за даним показником можна виділити такі «території ризику»: Старосамбірський, Сколівський, Сокальський райони та м. Червоноград.
показники
первинної

захворюваності на ГЕРХ були зареєстровані у Городоцькому, Миколаївському, Перемишлянському, Радехівському, Стрийському та Яворівському районах. У Мостиському районі та м. Трускавець і м. Стрий за період 2013-2016 роки не було зафіксовано жодного випадку первинної захворюваності на ГЕРХ (табл. 3).

За даними картодіаграми (рис. 3), найвищі рівні первинної захворюваності на ГЕРХ у 2016 році реєструються на півночі, півдні області та у Пустомитівському та Миколаївському районах, найнижчі або відсутні взагалі - в західних та східних районах Львівщини.

Аналізуючи гендерні особливості розподілу ГЕРХ у дітей Львівської області впродовж 2013-2016 років, виявлено вищий рівень патології серед дівчат у порівнянні $з$ хлопчиками.

За показником співвідношення, рівень поширеності ГЕРХ серед дівчат був в 1,05-1,37 рази вищим, ніж у хлопців і у міських поселеннях, і у сільській місцевості в усі роки спостереження, окрім 2014 року, коли ця патологія у хлопчиків, що проживають у містах, була вищою в 1,12 рази, ніж у дівчат. 
Таблиця 3.

Рівень первинної захворюваності на ГЕРХ серед дітей у розрізі районів Львівської області впродовж 2013-2016 років

\begin{tabular}{|c|c|c|c|c|c|c|c|c|}
\hline \multirow{2}{*}{ Території } & \multicolumn{4}{|c|}{ Абсолютні дані } & \multicolumn{4}{|c|}{$\begin{array}{c}\text { Випадків на } \\
1 \text { тис. дит. нас. }\end{array}$} \\
\hline & 2013 & 2014 & 2015 & 2016 & 2013 & 2014 & 2015 & 2016 \\
\hline \multicolumn{9}{|c|}{ Райони } \\
\hline Бродівський & 6 & 1 & 19 & 2 & 0,59 & 0,10 & 1,87 & 0,20 \\
\hline Буський & 5 & 8 & 6 & 2 & 0,64 & 1,02 & 0,75 & 0,25 \\
\hline Городоцький & 2 & 0 & 0 & 0 & 0,18 & 0 & 0 & 0 \\
\hline Дрогобицький & 1 & 3 & 1 & 1 & 0,08 & 0,24 & 0,08 & 0,08 \\
\hline Жидачівський & 1 & 5 & 1 & 4 & 0,10 & 0,48 & 0,10 & 0,39 \\
\hline Жовківський & 12 & 17 & 1 & 5 & 0,63 & 0,88 & 0,05 & 0,25 \\
\hline Золочівський & 3 & 2 & 1 & 2 & 0,27 & 0,18 & 0,09 & 0,18 \\
\hline Кам.-Бузький & 1 & 4 & 0 & 14 & 0,10 & 0,41 & 0 & 1,40 \\
\hline Миколаївський & 0 & 1 & 2 & 0 & 0 & 0,09 & 0,18 & 0 \\
\hline Перемишлянський & 1 & 0 & 1 & 0 & 0,16 & 0 & 0,16 & 0 \\
\hline Пустомитівський & 18 & 18 & 2 & 12 & 0,98 & 0,96 & 0,10 & 0,60 \\
\hline Радехівський & 0 & 2 & 4 & 2 & 0 & 0,24 & 0,49 & 0,24 \\
\hline Самбірський & 12 & 6 & 4 & 6 & 0,70 & 0,35 & 0,23 & 0,34 \\
\hline Сколівський & 22 & 23 & 19 & 19 & 2,39 & 2,48 & 2,01 & 2,01 \\
\hline Сокальський & 6 & 12 & 6 & 12 & 0,39 & 0,79 & 0,39 & 0,78 \\
\hline Ст. Самбірський & 69 & 91 & 42 & 6 & 5,62 & 7,40 & 3,38 & 0,48 \\
\hline Стрийський & 0 & 0 & 1 & 3 & 0 & 0 & 0,10 & 0,29 \\
\hline Турківський & 0 & 0 & 2 & 4 & 0 & 0 & 0,19 & 0,39 \\
\hline Яворівський & 0 & 3 & 9 & 4 & 0 & 0,13 & 0,38 & 0,17 \\
\hline Разом райони & 159 & 196 & 121 & 98 & 0,65 & 0,80 & 0,49 & 0,39 \\
\hline \multicolumn{9}{|c|}{ Міста } \\
\hline Львів & 10 & 60 & 44 & 33 & 0,10 & 0,56 & 0,41 & 0,30 \\
\hline Борислав & 0 & 1 & 1 & 1 & 0 & 0,16 & 0,16 & 0,16 \\
\hline Дрогобич & 0 & 1 & 4 & 1 & 0 & 0,08 & 0,30 & 0,07 \\
\hline Моршин & 1 & 1 & 0 & 0 & 1,40 & 1,42 & 0 & 0 \\
\hline Новий Розділ & 1 & 0 & 2 & 3 & 0,22 & 0 & 0,46 & 0,69 \\
\hline Червоноград & 13 & 19 & 23 & 13 & 1,08 & 1,57 & 1,87 & 1,05 \\
\hline Разом міста & 25 & 82 & 74 & 51 & 0,16 & 0,53 & 0,47 & 0,32 \\
\hline Разом Львівська обл. & 184 & 278 & 195 & 149 & 0,46 & 0,70 & 0,48 & 0,36 \\
\hline
\end{tabular}

Показник динаміки цього показника в обох гендерних групах $є$ додатнім, що свідчить про тенденцію до зростання за 4 аналізованих роки. Темп приросту поширеності ГЕРХ упродовж 2013-2016 pp. у сільській місцевості був у 2,45 рази вищим у дівчат, ніж у хлопчиків, а у міських поселеннях - незначно вищим у хлопчиків: $+229,63 \%$ проти $224,14 \%$ відповідно.

Рівень первинної захворюваності на ГЕРХ також $\epsilon$ вищим у дівчат, ніж у хлопчиків протягом 4-х років спостереження. Коефіцієнт співвідношення дівчат/хлопчиків був у межах від 1,12 (міські поселення 2015 р.) до 1,58 (міські поселення 2013 р.).

Причому, якщо в сільській місцевості цей показник зростає - від 1,14 у 2013 р. до 1,53 у 2016 р., що свідчить про більш інтенсивні зміни рівня первинної захворюваності у дівчат, ніж у хлопців на цій території, то у міських поселеннях навпаки - $є$ зниження цього показника: від 1,58 у 2013 р. до 1,19 у 2016 р., що свідчить про нівелювання гендерної ознаки за рівнем первинної захворюваності на ГЕРХ у містах у 2015-2016 роках.
Загальна тенденція рівня первинної захворюваності на ГЕРХ за 4 роки у Львівській області $\epsilon$ негативна і більш виражена (у 1,8 рази) у хлопчиків, ніж у дівчат. Це пов'язано із тенденцією до зниження цього показника у сільській місцевості: $\mathrm{T}_{\text {пр хл. }=-48,86}$ $\%, \mathrm{~T}_{\text {прдівч. }}=-31,00 \%$. Проте, у міських поселеннях в обох групах відбувається значне зростання захво-

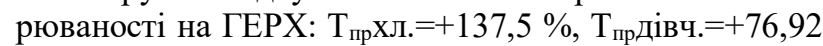
$\%$.

Аналіз внутрішньообласного розподілу поширеності ГЕРХ виявив високі рівні захворюваності впродовж 2013-2016 років одночасно у хлопчиків і дівчат у Старосамбірському, Сколівському, Сокальському, Буському та Жовківському районах, м. Львові та м. Червонограді (табл. 4).

Також, високі рівні поширеності ГЕРХ виявлено серед хлопчиків у м. Новий Розділ, а серед дівчат - у м. Моршин, причому у протилежної статі у цих містах захворюваність була відсутня (хлопчики м. Моршин) або реєструвались поодинокі випадки (дівчата м. Новий Розділ). 


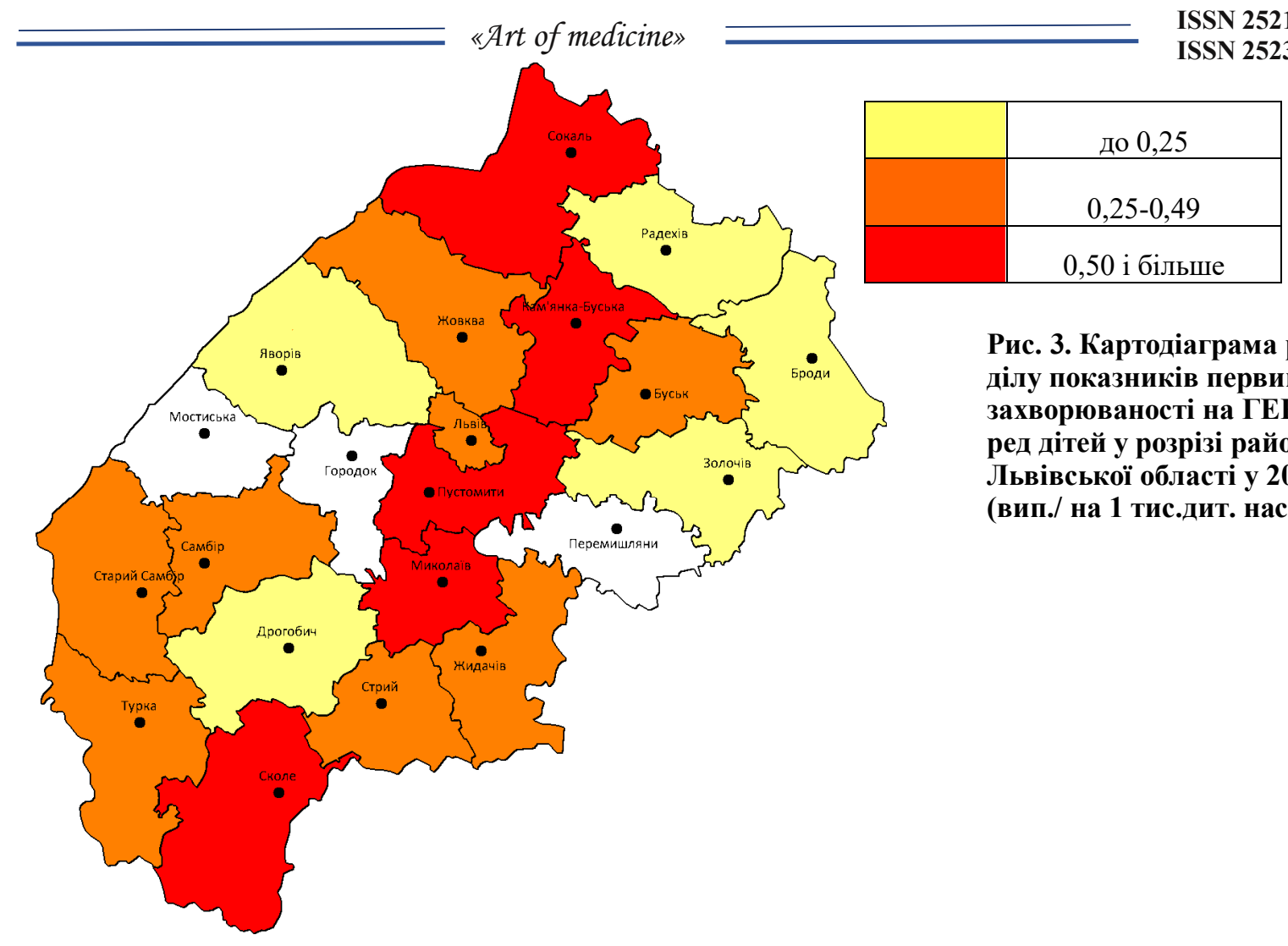

Рис. 3. Картодіаграма розподілу показників первинної захворюваності на ГЕРХ серед дітей у розрізі районів Львівської області у 2016 році (вип./ на 1 тис.дит. нас.)

Таблиця 4

Розподіл за статтю поширеності ГЕРХ серед дітей у розрізі районів Львівської області впродовж 2013-2016 років (випадків на 1тис. дітей відповідної групи)

\begin{tabular}{|l|c|c|c|c|c|c|c|c|c|c|}
\hline \multirow{2}{*}{ Територія } & \multicolumn{9}{|c|}{ Хлопчики } & \multicolumn{7}{|c|}{ Дівчата } \\
\cline { 2 - 13 } & 2013 & 2014 & 2015 & 2016 & $\mathrm{~T}_{\text {пр }}$ & 2013 & 2014 & 2015 & 2016 & $\mathrm{~T}_{\text {пр }}$ \\
\hline Бродівський & 0,39 & 0,19 & 1,34 & 0,19 & $-51,28$ & 0,81 & 0,2 & 2,81 & 0,99 & 22,22 \\
\hline Буський & 1,49 & 2,44 & 3,4 & 3,36 & 125,50 & 0,79 & 1,53 & 1,53 & 1,26 & 59,49 \\
\hline Городоцький & 0,17 & 0,17 & 0 & 0 & $-100,0$ & 0,18 & 0,17 & 0 & 0 & $-100,00$ \\
\hline Дрогобицький & 0,16 & 0,47 & 0,47 & 0,46 & 187,50 & 0 & 0,16 & 0,32 & 0,47 & 193,75 \\
\hline Жидачівський & 0,19 & 1,85 & 0 & 0,54 & 184,21 & 0 & 3,39 & 0,2 & 0,39 & $-88,50$ \\
\hline Жовківський & 0,61 & 1,78 & 1,47 & 1,65 & 170,49 & 0,84 & 2,25 & 1,93 & 1,71 & 103,57 \\
\hline Золочівській & 0,18 & 0,17 & 0,35 & 0,51 & 183,33 & 0,37 & 0,37 & 0,36 & 0,54 & 45,95 \\
\hline Кам.-Бузький & 0,2 & 0 & 0 & 2,08 & 940,00 & 0 & 1,48 & 1,05 & 3,55 & 139,86 \\
\hline Миколаївський & 0 & 0 & 0,18 & 0,18 & & 0 & 0,19 & 0,37 & 0,37 & 94,74 \\
\hline Перемишлянський & 0,31 & 0,31 & 0 & 0 & $-100,0$ & 0 & 0 & 0,32 & \multirow{2}{*}{0} & \\
\hline Пустомитівський & 0,83 & 0,91 & 0,6 & 0,69 & $-16,87$ & 1,09 & 1,49 & 1,06 & \multirow{2}{*}{1,15} & 5,50 \\
\hline Радехівський & 0 & 0,72 & 0,47 & 0,23 & $-68,06$ & 0 & 0,25 & 0,5 & 1,47 & 488,00 \\
\hline Самбірський & 1,85 & 0,33 & 0,99 & 0,97 & $-47,57$ & 1,73 & 0,87 & 0,35 & 0,85 & $-50,87$ \\
\hline Сколівський & 2,32 & 2,28 & 2,27 & 2,24 & $-3,45$ & 4,64 & 4,55 & 3,66 & 3,62 & $-21,98$ \\
\hline Сокальський & 1,16 & 1,92 & 1,9 & 2,25 & 93,97 & 1,07 & 1,73 & 2,12 & 2,88 & 169,16 \\
\hline Старосамбірський & 5,26 & 6,96 & 5,5 & 0,78 & $-85,17$ & 5,98 & 7,72 & 7,52 & 1,13 & $-81,10$ \\
\hline Стрийський & 0 & 0 & 0 & 0 & & 0 & 0,2 & 0,41 & 1 & 400,00 \\
\hline Турківський & 0 & 0 & 0,56 & 0,18 & & 0 & 0 & 0,2 & 0,58 & \\
\hline Яворівський & 0 & 0 & 0,49 & 0,56 & & 0 & 0,26 & 0,86 & 1,02 & 292,31 \\
\hline Львів & 0,44 & 1,37 & 1,19 & 1,39 & 215,91 & 0,3 & 0,99 & 1,12 & 1,24 & 313,33 \\
\hline Борислав & 0 & 0,65 & 0,32 & 0 & $-100,0$ & 0 & 0,33 & 0,32 & 0,64 & 93,94 \\
\hline Дрогобич & 0 & 0 & 0,15 & 0,44 & & 0 & 0,15 & 0,59 & 0,29 & 93,33 \\
\hline Моршин & 0 & 0 & 0 & 0 & & 2,75 & 5,62 & 5,56 & 5,51 & 100,36 \\
\hline Новий Розділ & 0,43 & 0 & 0,86 & 1,28 & 197,67 & 0 & 0 & 0 & 0,93 & \\
\hline Червоноград & 1,3 & 2,56 & 3,79 & 4,21 & 223,85 & 2,85 & 4,12 & 6,36 & 5,98 & 109,82 \\
\hline
\end{tabular}


Найнижчі рівні за даним показником у обох статей були зареєстровані у Городоцькому, Миколаївському, Перемишлянському, Турківському районах, м. Борислав і м. Дрогобич. Жодного випадку загальної захворюваності на ГЕРХ серед обох груп за статтю не було діагностовано у Мостиському районі, м. Стрий та м. Трускавець, окрім того ще серед хлопчиків - у Стрийському районі та м. Моршин. Тоді як серед дівчат випадки поширення ГЕРХ реєструвались у решті серед всіх наведених районів.

Високі показники динаміки (темп приросту більше $+100 \%$ ) одночасно у обох групах за статтю мали місце і серед районів 3 тривалим високим рівнем захворюваності (Жовківський, Сокальський, м. Львів, м. Червоноград), і серед районів із низьким рівнем (Дрогобицький район), або високим тільки у 2016 році (Кам'янка-Бузький район).

Окрім того, значні тенденції до зростання показника поширення ГЕРХ були у хлопчиків Жидачівського, Золочівського районів та м. Новий

Розділ. Серед дівчат ці показники були високими у Радехівському, Стрийському, Яворівському районах та м. Моршин. Дані тенденції були характерні для районів із низькими показниками поширеності ГЕРХ та міст із високими показниками.

Значний від'ємний приріст цього показника серед хлопчиків і дівчат реєструвався у Городоцькому районі, виключно серед хлопчиків - у Перемишлянському районі та м. Борислав. Зниження загальної захворюваності на ГЕРХ у хлопчиків при зростанні її у дівчат було у Бродівському, Пустомитівському, Радехівському районах та м. Борислав. Навпаки, зниження iii у дівчат при зростанні у хлопчиків відбувалось лише у Жидачівському районі.

За показниками первинної захворюваності на ГЕРХ високі їі рівні впродовж 4-х аналізованих років одночасно у обох групах за статтю спостерігались у Сколівському та Старосамбірському районах, м. Львів та м. Червоноград (табл. 5).

Таблиця 5

Розподіл за статтю первинної захворюваності на ГЕРХ серед дітей у розрізі районів Львівської області упродовж 2013-2016 років (випадків на 1 тис. дітей відповідної групи)

\begin{tabular}{|c|c|c|c|c|c|c|c|c|c|c|}
\hline \multirow{2}{*}{ Територія } & \multicolumn{5}{|c|}{ Хлопчики } & \multicolumn{5}{|c|}{ Дівчата } \\
\hline & 2013 & 2014 & 2015 & 2016 & $\mathrm{~T}_{\text {пр }}$ & 2013 & 2014 & 2015 & 2016 & $\mathrm{~T}_{\text {пр }}$ \\
\hline Бродівський & 0,39 & 0,19 & 1,34 & 0 & $-100,00$ & 0,81 & 0 & 2,41 & 0,4 & $-50,62$ \\
\hline Буський & 0,74 & 1,47 & 0,73 & 0,48 & $-35,14$ & 0,52 & 0,51 & 0,76 & 0 & $-100,00$ \\
\hline Городоцький & 0,17 & 0 & 0 & 0 & $-100,00$ & 0,18 & 0 & 0 & 0 & $-100,00$ \\
\hline Дрогобицький & 0,16 & 0,31 & 0 & 0 & $-100,00$ & 0 & 0,16 & 0,16 & 0,16 & 0,00 \\
\hline Жидачівський & 0,19 & 0,18 & 0 & 0,54 & 184,21 & 0 & 0,8 & 0,2 & 0,2 & $-75,00$ \\
\hline Жовківський & 0,4 & 0,69 & 0 & 0,19 & $-52,50$ & 0,84 & 1,02 & 0,1 & 0,3 & $-64,29$ \\
\hline Золочівській & 0,18 & 0,17 & 0,17 & 0,17 & $-5,56$ & 0,37 & 0,18 & 0 & 0,18 & $-51,35$ \\
\hline Кам.-Бузький & 0,2 & 0 & 0 & 1,33 & 565,00 & 0 & 0,85 & 0 & 1,46 & \\
\hline Миколаївський & 0 & 0 & 0,18 & 0 & & 0 & 0,19 & 0,18 & 0 & \\
\hline Перемишлянський & 0,31 & 0 & 0 & 0 & $-100,00$ & 0 & 0 & 0,32 & 0 & \\
\hline Пустомитівський & 0,83 & 0,61 & 0,1 & 0,4 & $-51,81$ & 1,09 & 1,27 & 0,11 & 0,84 & $-22,94$ \\
\hline Радехівський & 0 & 0,24 & 0,47 & 0 & $-100,00$ & & 0,25 & 0,5 & 0,49 & 96,00 \\
\hline Самбірський & 1,01 & 0,33 & 0,66 & 0,49 & $-51,49$ & 1,04 & 0,69 & 0 & 0,51 & $-50,96$ \\
\hline Сколівський & 2,1 & 1,66 & 1,65 & 1,63 & $-22,38$ & 2,65 & 3,25 & 2,37 & 2,34 & $-11,70$ \\
\hline Сокальський & 0,52 & 0,89 & 0,38 & 0,63 & 21,15 & 0,27 & 0,67 & 0,4 & 0,92 & 240,74 \\
\hline Старосамбірський & 5,26 & 6,96 & 3,14 & 0,31 & $-94,11$ & 5,98 & 7,72 & 3,59 & 0,65 & $-89,13$ \\
\hline Стрийський & 0 & 0 & 0 & 0 & & 0 & 0 & 0,2 & 0,6 & \\
\hline Турківський & 0 & 0 & 0,19 & 0,18 & & 0 & 0 & 0,2 & 0,58 & \\
\hline Яворівський & 0 & 0 & 0,32 & 0,16 & & 0 & 0,26 & 0,43 & 0,17 & $-34,62$ \\
\hline Львів & 0,09 & 0,59 & 0,44 & 0,31 & 244,44 & 0,1 & 0,56 & 0,39 & 0,31 & 210,00 \\
\hline Борислав & 0 & 0 & 0,32 & 0 & & 0 & 0,33 & 0 & 0,32 & \\
\hline Дрогобич & 0 & 0 & 0,15 & 0 & & 0 & 0,15 & 0,44 & 0,15 & 0,00 \\
\hline Моршин & 0 & 0 & 0 & 0 & & 2,75 & 2,81 & 0 & 0 & $-100,00$ \\
\hline Новий Розділ & 0,43 & 0 & 0,86 & 0,43 & 0,00 & 0 & 0 & 0 & 0,93 & \\
\hline Червоноград & 0,65 & 1,12 & 1,26 & 0,94 & 44,62 & 1,51 & 1,98 & 2,45 & 1,13 & $-25,17$ \\
\hline
\end{tabular}

Виключно у хлопчиків цей показник був більше середнього у Буському, Самбірському районах та м. Новий Розділ, тільки у дівчат - у Пустомитівському районі та м. Моршин.

Мінімальні рівні первинної захворюваності на ГЕРХ у обох групах за статтю були у Городоцькому, Дрогобицькому, Жовківському, Золочівському, Миколаївському, Перемишлянському, Турківському та Яворівському районах, м. Борислав та м. Дрогобич. У Стрийському районі та м. Моршин не було за- реєстровано жодного випадку за цим показником серед хлопчиків, тоді як серед дівчат первинна захворюваність реєструвалась у всіх наведених територіях Львівської області.

Значна позитивна динаміка первинної захворюваності на ГЕРХ при темпі приросту більше +100 $\%$ спостерігалась у хлопчиків Жидачівського та Кам'янка-Бузького районів, у дівчат Сокальського району та у обох групах дітей м. Львова. Від'ємна динаміка цього показника (-100 \%) мала місце у хлоп- 
чиків Бродівського, Дрогобицького, Перемишлянського, Радехівського районів, у дівчат Буського району та м. Моршин, у обох цих групах у Городоцькому районі.

Різнонаправлені показники були на трьох територіях: у Радехівському районі - при зростанні захворюваності у дівчат захворюваність у хлопчиків знижувалась; у Жидачівському районі та м. Червоноград - навпаки, при зростанні показників у хлопчиків у дівчат відбувалось зниження. На решті територій показники первинної захворюваності на ГЕРХ або суттєво не змінювались, або мали незначну тенденцію до зниження рівня.

За показником 2016 року (рис. 4), встановлено, що майже у всіх районах поширеність та первинна захворюваність на ГЕРХ у дівчат $є$ вищою, ніж у хлопців. Окрім районів Буського, Самбірського, Жидачівського та міст Львів, Дрогобич та Новий Розділ, де показник поширення був вищим у хлопчиків, ніж у дівчат. За показником первинної захворюваності, лише у двох районах була така ж ситуація: Буський i Жидачівський.

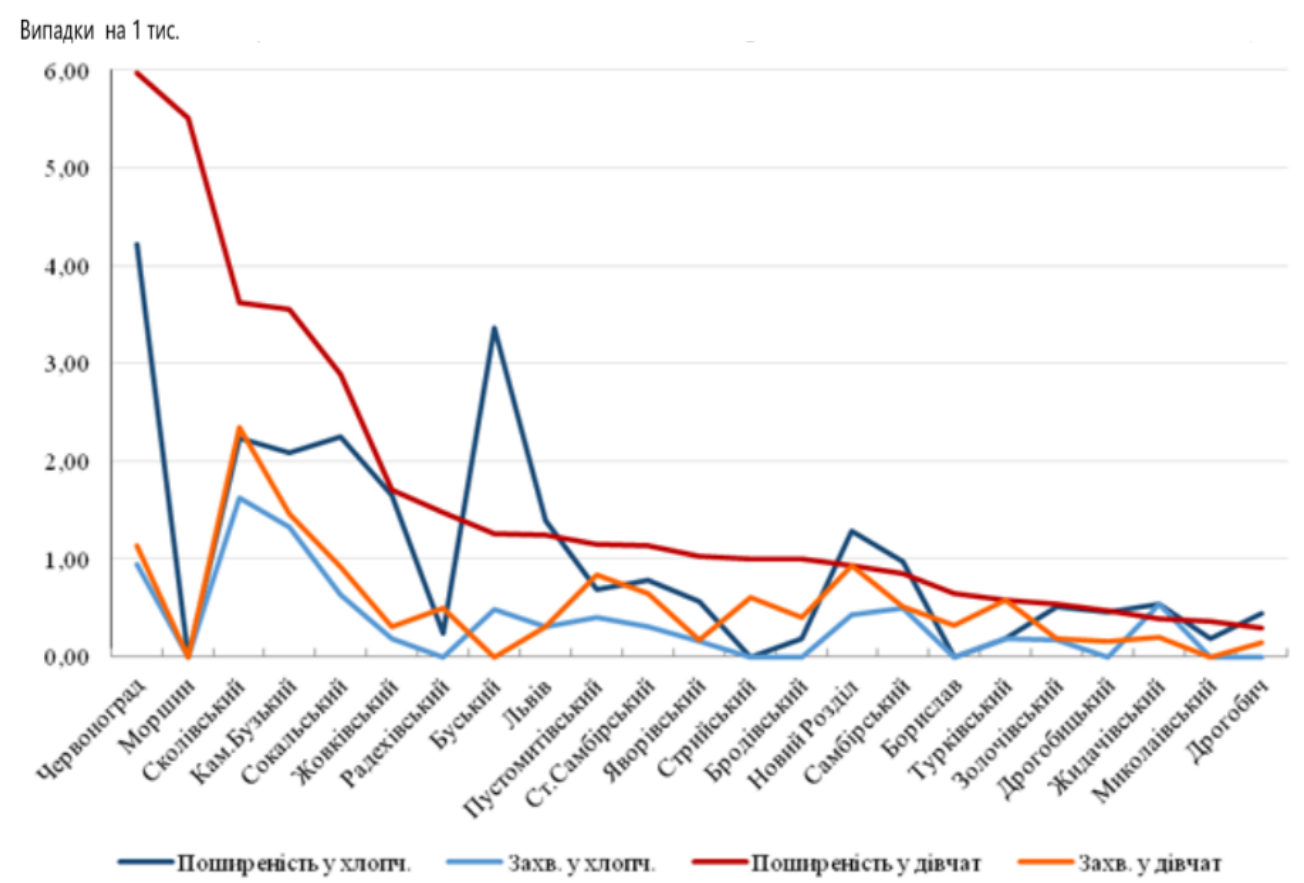

Рис. 4. Розподіл за статтю поширення та первинної захворюваності на ГЕРХ серед дітей у розрізі районів Львівської об̆ласті у 2016 році (випадків на 1 тис. дітей відповідної статі та території)

Найвищі рівні поширення ГЕРХ у обох групах за статтю були у м. Червонограді. Серед дівчат дуже високі рівні поширення були у м. Моршин, Сколівському та Кам'янка-Бузькому районах. Причому у останньому районі такий високий рівень реєструвався тільки у 2016 році. Серед хлопчиків високі рівні поширення ГЕРХ спостерігались у Буському, Сокальському, Кам'янка-Бузькому та Сколівському районах.

За показником первинної захворюваності, високі значення були у хлопчиків i дівчат Сколівського, Кам'янка-Бузького районів та м. Червоноград.

При аналізі розподілу захворюваності на ГЕРХ за віковими групами встановлено, що на всіх територіях Львівщини та в усі роки спостереження вища захворюваність була у школярів, ніж у дітей дошкільного віку: коефіцієнт співвідношення при загальній захворюваності був у межах від 1,91 (2013 рік) до 4,95 (2016 рік); при первинній - від 1,19 (2013 рік) до 3,80 (2016 рік). Більш виражена різниця між віковими групами була у дітей міських поселень у порівнянні 3 сільськими. Загалом спостерігається тенденція до зниження захворюваності на ГЕРХ у групі дітей 0-6 років та тенденція до зростання у групі дітей 7-14 років. Однак у міських поселеннях $\epsilon$ виражена тенденція до зростання у всіх вікових групах.

Середній відсоток моніторингу дітей із ГЕРХ становив від 48,46 $\pm 3,10 \%$ у 2013 році до $77,45 \pm 1,93$ \% у 2016 році (табл.9). Частка моніторингу дітей із ГЕРХ була у 1,25-2,32 рази вищою у містах, ніж у сільській місцевості. У повному обсязі (100\%) моніторування даної нозології серед дітей за 4 роки спостерігалось лише у м. Моршин, у більшості років - у Дрогобицькому, Миколаївському, Перемишлянському, Яворівському районах та м. Дрогобич.

До районів із відносно високими показниками моніторування (більше 80\%) протягом більшості років можна віднести Буський, Золочівський, Сокальський райони, м. Львів та м. Червоноград.

Зіставивши дані картодіаграми моніторингу ГЕРХ за 2016 рік (рис. 5) із картодіаграмою поширеності ГЕРХ (рис. 2) та врахувавши результати вищенаведеного аналізу, можна визначити несприятливі території щодо подальшого прогнозу росту захворюваності на ГЕРХ серед дітей. 

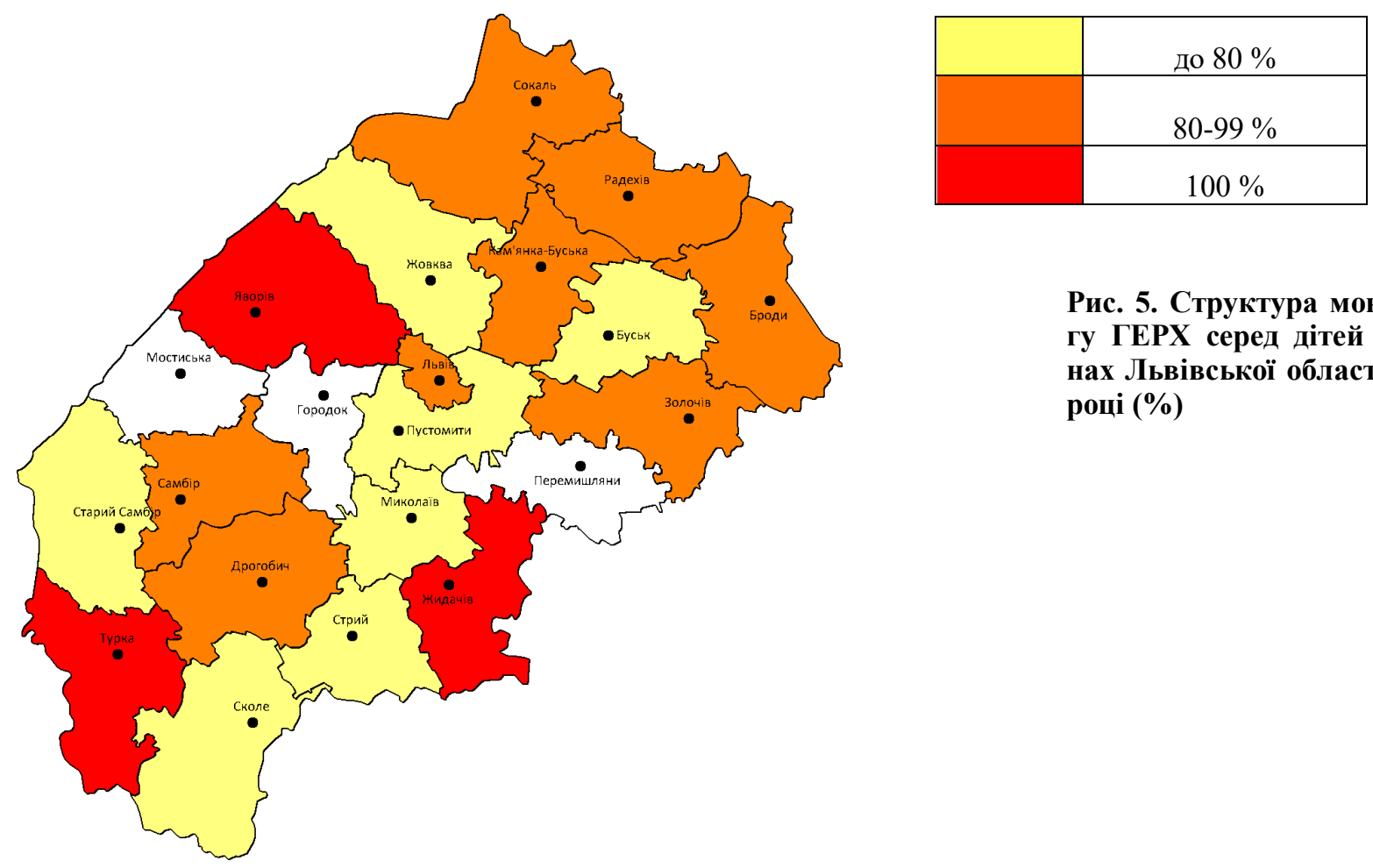

Рис. 5. Структура моніторингу ГЕРХ серед дітей у районах Львівської області у 2016 році (\%)

До таких територій належать: Сколівський, Буський та Жовківський райони, оскільки у них, при загальній тенденції до зростання за 4 роки та високих рівнях захворюваності у 2016 році, спостерігаються низькі рівні моніторування ГЕРХ. Територіями підвищеного ризику можна вважати Старосамбірський, Сокальський та Кам'янка-Бузький райони. До територій відносного благополуччя можна віднести Турківський, Яворівський та Миколаївський райони.

Результати нашого дослідження збігаються зі світовими даними щодо стрімкого зростання захворюваності та поширення ГЕРХ [5], в тому числі і серед дитячого населення [7]. Рівень первинної та загальної захворюваності на ГЕРХ $є$ вищим у дівчат порівняно 3 хлопцями протягом даних 4-х років спостереження, що співпадає 3 результатами інших досліджень [5]. Крім того, було виявлено, що серед дітей шкільного віку захворюваність на ГЕРХ була вищою, ніж серед дошкільнят.

\section{Висновки:}

1. Тенденція до зростання загальної захворюваності на ГЕРХ серед дітей $є$ більш вираженою у міських поселеннях.

2. За показником поширення ГЕРХ так званими «територіями ризику» можна вважати: Старосамбірський, Сколівський, Сокальський, Буський райони та м. Червоноград і м. Моршин.

3. Рівень первинної захворюваності та поширеності ГЕРХ є вищим у дівчат у порівнянні 3 хлопчиками впродовж 4-х років спостереження.

4. На всіх територіях Львівщини та в усі 4 роки спостереження вища захворюваність виявлялась у школярів порівняно з дітьми дошкільного віку.

\section{References:}

1. Aliannejad R, Karbasi A, Ghanei M, Sanamy M, Alaeddini F, Harandi A. Frequency distribution of gastro esophageal reflux disease in inhalation injury: A historical cohort study. Journal of Research in Medical Sciences. $2015 ; 20(7): 636$.

2. Overview | Gastro-oesophageal reflux disease in children and young people: diagnosis and management | Guidance | NICE [Internet]. Nice.org.uk. 2019, [cited 02 May 2019]. Available from: https://www.nice.org.uk/guidance/ng1

3. Esposito C, Roberti A, Escolino M, Cerulo M, Settimi A, Farina A et al. Management of gastroesophageal reflux disease in pediatric patients: a literature review. Pediatric Health, Medicine and Therapeutics. 2015; 1.

4. Santos T, Burgos M, Lemos M, Cabral P. Clinical and nutritional aspects in obese women during the first year after ROUX-EN-Y gastric bypass. ABCD Arquivos Brasileiros de Cirurgia Digestiva (São Paulo). 2015; 28(1):56-60.

5. Zubaryenko OV, Kravchenko TYU. Cuchacnyy pohlyad na hactroezofahealnu reflyukcnu khvorobu u ditey. Perynatolohiya i pediatriya. 2013; 1(53):114-122.

6. Gastro-oesophageal reflux in children and young people. The Pharmaceutical Journal. 2014.

7. Zubarenko OV, Kravchenko TYU, Locyeva KO. Hactroezofahealna reflyukcna khvoroba u ditey: cuchacnyy pohlyad na patohenez i kliniku. Zdorovya dytyny. 2012; 1(36).

8. de Benedictis F, Bush A. Respiratory manifestations of gastro-oesophageal reflux in children. Archives of Disease in Childhood. 2017; archdischild-2017-312890. 
УДК 616.329 / .33-002-053.2-036.22 (477.83)

ЭПИДЕМИОЛОГИЧЕСКИЕ ОСОБЕННОСТИ РАСПРОСТРАНЕНИЯ ГАСТРОЭЗОФАГЕАЛЬНОЙ РЕФЛЮКСНОЙ БОЛЕЗНИ СРЕДИ ДЕТЕЙ ЛЬВОВСКОЙ ОБЛАСТИ

М.И. Дац-Опока, Н.С. Космынина, Л.Ф. Бура-Ярошевич, Е.Р. Трутяк

Львовский национальный медицинский университет имени Данила Галиикого, кафедра пропедевтики педиатрии и медииинской генетики,

г. Львов, Украина,

ORCID ID: 0000-0002-2797-2462,

ORCID ID: 0000-0003-0422-7002,

ORCID ID: 0000-0002-3244-2191,

ORCID ID: 0000-0002-7777-9927

e-mail:martadats@gmail.com

Резюме. Целью исследования было проанализировать уровень заболеваемости гастроэзофагеальной рефлюксной болезнью (ГЭРБ) среди детей до 14 лет во Львовской области.

Проведен ретроспективный анализ эпидемиологии ГЭРБ среди детей Львовской области в 2013-2016 годах.

Согласно результатам, наблюдается тенденция к росту общей заболеваемости ГЭРБ среди детей Львовской области - с 0,66 случаев на 1000 детского населения в 2013 году до 1,15 сл. / 1тис.дет.нас. в 2016 году (темп прироста Тпр $=+66,67 \%$ ). Самый высокий уровень общей заболеваемости как в целом во Львовской области, так и в городах региона наблюдался в 2015 году - 196 случаев. В сельской местности высокий уровень ГЭРБ был в 2014 году 292 случая.

Самый высокий уровень ГЭРБ зарегистрировано в Старосамборском районе - 7,40 сл. / 1тис.дет.нас. (2014), а среди городов - в г. Червоноград - 5,15 сл. / 1тис.дет.нас. (2016). Заболеваемость на ГЭРБ выше у девушек, чем у мальчиков на протяжении всех лет наблюдения. В группе детей 0-6 лет заболеваемость ГЭРБ снижается, а в группе детей 714 лет - растет.

Подытоживая, общая заболеваемость ГЭРБ среди детей Львовской области растет, что более выражено в городских поселениях. За последний анализируемый год высокие уровни общей заболеваемости ГЭРБ регистрируются на севере и юге области, низкие или отсутствующие - в центральных, западных и восточных районах Львовщины. «Территориями риска» по показателю распространения ГЭРБ являются: Старосамборский, Сколевский, Сокальский, Жовковский районы, г. Червоноград и г. Моршин. Уровень первичной и общей заболеваемости ГЭРБ выше у девушек, чем у мальчиков. На всех территориях Львовщины за все годы наблюдения высокая заболеваемость была у школьников, по сравнению с детьми дошкольного возраста.

Ключевые слова: гастроэзофагеальная рефлюксная болезнь, дети, Львовская область, епидемилогия.
UDC 616.329 / .33-002-053.2-036.22 (477.83)

\section{EPIDEMIOLOGICAL PECULIARITIES OF GAS- TROESOPHAGEAL REFLUX DISEASE OCCUR- RENCE AMONG CHILDREN IN LVIV REGION}

M.I. Dats-Opoka, N. S. Kosmynina,

L. F. Bura-Yaroshevych, O. R.Trutiak

Danylo Halytsky Lviv National Medical University, Department of Propedeutics Pediatrics and

Medical Genetics, Lviv, Ukraine,

ORCID ID: 0000-0002-2797-2462,

ORCID ID: 0000-0003-0422-7002,

ORCID ID: 0000-0002-3244-2191,

ORCID ID: 0000-0002-7777-9927

e-mail:martadats@gmail.com

Abstract. The aim of the study was to identify and analyze the epidemiology of gastroesophageal reflux disease (GERD) among children under 14 years old in Lviv region.

A retrospective analysis of the epidemiology of GERD among children of Lviv region during 2013-2016 years was conducted.

There were following criteria for inclusion in the study: 1) children under 14 years old, diseased with GERD, who were living during the time of the study in Lviv and Lviv region 2) voluntary informed consent to participate in the study was received. There were following eexclusion criteria: 1) children over 14 years old, 2) children from other regions of Ukraine. 3) refusal from participation in the study at any stage. All children were divided into groups according to their gender, age and place of residence, as well as according to different years of observation.

According to the results, there is tendency of increasing of the general GERD morbidity in children from Lviv region from 0.66 cases per 1000 children in 2013 to 1.15 cases per 1000 children in 2016 (growth rate $\mathrm{T}_{\mathrm{pr}}=+$ $66.67 \%$ ). The highest level of GERD was registered in Starosambirskyi district- 7.40 cases/ 1 thousand people (2014), and as for cities - in Chervonograd - 5,15 cases/1 thousand people (2016). The incidence of GERD is higher in girls than in boys during all years of observation. The incidence of GERD decreases in the group of children under 6 years, while it increases in the group of children 7-14 years old.

In summary, the overall incidence of GERD among children in the Lviv region is increasing, which is more pronounced in urban settlements. According to the prevalence of GERD there are following "territories of risk": Starosambirsky, Skolivsky, Sokalsky and Busky districts; Chervonograd and Morshyn cities. The level of primary and general morbidity in GERD is higher in girls than in boys. The highest incidence was noted in schoolage children than in pre-schoolers in all areas of Lviv region and during all years of observation.

The average percentage of coverage by monitoring of children with GERD ranged from $48.46 \pm 3.10 \%$ in 2013 to $77.45 \pm 1.93 \%$ in 2016 . The coverage by the monitoring of children with GERD in cities was 1.252.32 times higher than in rural areas. $100 \%$ coverage of monitoring of children with GERD was observed in 
Morshyn city only during all years of observation and in Drohobych, Mykolaiv, Peremyshlyany, Yavoriv districts, Drohobych city during most years of observation; over $80 \%$ - in Busk, Zolochiv, Sokal districts, Lviv and Chervonograd cities during most years of observation. Comparing diagrams with data of the monitoring of the GERD morbidity during the last year of the study with the diagrams of the general morbidity and according to the results of the above-mentioned analysis, it is possible to determine the unfavorable territories as for the further forecasting of the growth of the incidence of GERD among children. Following districts Skole, Busk and
Zhovkva belongs to such territories, since they are characterized by high level of morbidity and low coverage of monitoring during all period of study. Starosambirsky, Sokalsky and Kamianka-Buzsky districts can be considered as territories of high risk of GERD morbidity. Relatively favorable are the Turka, Yavoriv and Mykolaiv districts. The results of current study coincide with global data on the rapid increase in the incidence and spreading of GERD, including pediatric population.

Keywords: gastroesophageal reflux disease, children, Lviv region, epidemiology.

Стаття надійшла в редакцію 13.06.2019 p. 